\title{
Effect of enzymic treatment on nutritive value of leaf fraction of wheat straw
}

\author{
FB Castro 1, ER Ørskov 2 \\ 1/nstituto de Zootecnia, Nova Odessa / SP, Brazil ; ${ }^{2}$ Rowett Research Institute, Aberdeen, UK
}

It has been shown that leaf fraction of cereal straws responds more to polysaccharidase treatment compared to internode and node fractions (Nakashima and Ørskov, 1988, Anim Prod, 48, 543-551). The aim of this study was to determine the effect of enzymic treatment conditions, ie enzyme loading, incubation period and moisture content, on nutritive value of leaf of wheat straw, variety Mercia.

A factorial design experiment $(3 \times 3 \times 3)$ was completed to study the effect of enzyme loading (4, 8 and 16 IU AVICELase/g of substrate), incubation period ( 7,14 and 21 days) and moisture $(30,40$ and $50 \%)$ on the extent of cell wall hydrolysis (cell wall and soluble sugar content) and nutritive value (in vitro gas production technique).

Nutritive value, as measured by the rate of gas production (c value), of enzymic-treated samples was always higher $(P<0.05)$ than control sample. It was also observed that, within enzymic-treated samples, enzyme loading and incubation period did not affect nutritive value. However, a significant $(P<0.05)$ but small negative effect on soluble sugar content was observed when low enzyme loading (4 IU) and short incubation period ( 7 days) were applied. Moisture content below $40 \%$ affected negatively both soluble sugar content and $\mathrm{c}$ value.

It can be concluded that enzymic treatment can improve the quality of some fibrous crop residues, eg leaf of cereal straw. Such improvement can be achieved within a short period ( $<1$ week) and with a small quantity of enzymes (<4 IU AVICELase/g substrate) when moisture content is kept above critical levels $(\approx 40 \%$ ).

\begin{tabular}{|c|c|c|c|c|}
\hline & & cell wall $(\%)$ & soluble sugar $(\%)$ & c value $\left(h^{-1}\right)$ \\
\hline control sample & & 76.7 & 2.73 & 0.031 \\
\hline \multirow[t]{3}{*}{ enzyme loading (IU/g substrate) } & 4 & 70.4 & 5.97 & 0.040 \\
\hline & 8 & 65.6 & 8.26 & 0.041 \\
\hline & 16 & 63.7 & 9.45 & 0.041 \\
\hline \multirow[t]{3}{*}{ incubation period (days) } & 7 & 70.1 & 6.11 & 0.041 \\
\hline & 14 & 65.2 & 9.01 & 0.040 \\
\hline & 21 & 64.8 & 8.75 & 0.041 \\
\hline \multirow[t]{3}{*}{ moisture content (\%) } & 30 & 70.4 & 6.53 & 0.036 \\
\hline & 40 & 66.4 & 8.40 & 0.043 \\
\hline & 50 & 63.5 & 8.94 & 0.044 \\
\hline
\end{tabular}

